\title{
KETERAMPILAN TIK GURU PRODUKTIF SMK DI KABUPATEN HULU SUNGAI UTARA DAN IMPLEMENTASINYA DALAM PEMBELAJARAN
}

\author{
Herry Fitriyadi \\ SMK Negeri 2 Amuntai \\ herr_fitrov@yahoo.co.id
}

\begin{abstract}
Abstrak: Keterampilan TIK Guru Produktif SMK di Kabupaten Hulu Sungai Utara dan Implementasinya dalam Pembelajaran. Guru sebagai aktor utama dalam proses pendidikan dituntut harus dengan cepat memperbaharui pengetahuan, keterampilan, dan kompetensinya dalam bidang Teknologi Informasi dan Komunikasi (TIK), tak terkecuali guru produktif Sekolah Menengah Kejuruan (SMK), dalam realitas masih minimnya implementasi TIK dalam pembelajaran dan adanya kendala internal dan eksternal SMK dalam pelaksanaan program TIK. Berdasarkan hal-hal tersebut, penelitian ini dilakukan untuk menginvestigasi penguasaan keterampilan TIK guru produktif SMK dan implementasi TIK dalam pembelajaran produktif SMK, serta mengidentifikasi kendala-kendala yang menjadi penghambat implementasi TIK dalam pembelajaran produktif SMK di Kabupaten Hulu Sungai Utara Provinsi Kalimantan Selatan. Kesimpulan hasil penelitian ini sebagai berikut: 1) Keterampilan TIK guru produktif SMK secara keseluruhan termasuk dalam kategori rendah. 2) Implementasi TIK dalam pembelajaran produktif SMK secara keseluruhan termasuk dalam kategori menengah. 3) Kendala-kendala implementasi TIK dalam pembelajaran produktif SMK berkaitan dengan kebijakan pemerintah daerah, pendanaan program, pengembangan profesional di bidang TIK, ketersediaan sumber daya TIK, dan penggunaan TIK di sekolah.
\end{abstract}

Kata kunci: keterampilan TIK, implementasi TIK

\section{THE ICT SKILLS OF PRODUCTIVE TEACHERS IN VHS IN THE REGENCY OF HULU SUNGAI UTARA AND THE IMPLEMENTATION IN TEACHING}

\begin{abstract}
The ICT Skills of Productive Teachers in VHS in the Regency of Hulu Sungai Utara and the Implementation in Teaching. The teachers as the main actors in the process of education is required to quickly renew their knowledge, skills and competence in the field of Information and Communicaton Technology (ICT), no exception vocational high schools (VHS) productive teachers', in reality the lack of implementation of ICT in learning, and the internal and external constraints in the implementation of ICT in VHS. Based on these things, this study was conducted to investigate the ICT skill mastery of productive teachers in VHS and the ICT implementation in the productive teaching in VHS, and to identify the constraints that inhibit theICT implementation in productive teaching in VHS in the Regency of HSU, the Province of South Kalimantan. The conclusions of the study are as follows. 1) The VHS productive teachers' ICT skills in general are in the low category. 2) The ICT implementation in productive teaching in VHS in general is in the moderate category. 3) The constraints in the ICT implementation in productive teaching in VHS are related to the local government's policies, program funding, professional development in ICT, availability of ICT resources, and ICT utilization in schools.
\end{abstract}

Keywords: ICT skills, ICT implementation 


\section{PENDAHULUAN}

Tantangan pendidikan pada abad ke-21 adalah membangun masyarakat berpengetahuan (knowledge-based society) yang dapat dibangun melalui pengintegrasian Teknologi Informasi dan Komunikasi (TIK) dalam proses pembelajaran. Dalam konteks pendidikan, sesungguhnya peran TIK adalah sebagai "enabler" atau alat untuk memungkinkan terjadinya proses pembelajaran yang efektif dan efisien serta menyenangkan. Dalam hal ini TIK dijadikan sebagai sarana untuk mencapai tujuan, bukan tujuan itu sendiri.

Dalam pendidikan modern, guru dituntut untuk mampu mengintegrasikan TIK dalam proses pembelajaran. Dilihat dari sisi peran TIK bagi guru, maka pengintegrasian TIK dalam proses pembelajaran seharusnya memungkinkan dirinya untuk: (1) menjadi fasilitator, kolaborator, mentor, pelatih, pengarah dan teman belajar dan (2) dapat memberikan pilihan dan tanggung jawab yang besar kepada siswa untuk mengalami peristiwa belajar (UNESCO, 2002: 22-23).

Guru sebagai aktor utama dalam proses pendidikan di sekolah perlu mendapatkan perhatian lebih melalui kegiatan pelatihan dan pendidikan yang sistematis dalam penguasaan TIK. Guru yang dituntut harus dengan cepat mengupdate pengetahuan, keterampilan, dan kompetensinya dalam bidang TIK, ternyata tidak dapat begitu saja dengan mudah dalam upaya menguasai bidang TIK ini. Banyak kendala mulai dari faktor usia, dukungan sarana peralatan, kesempatan, dukungan kebijakan dari atasan, hingga ketersediaan infrastruktur di sekolah yang tidak merata dan tidak dengan mudah bisa disesuaikan.

Realitas saat ini guru-guru di Indonesia pada umumnya masih banyak yang belum mengimplementasikan TIK dalam pembelajaran. Di sisi lain, ketersediaan sarana dan prasarana yang lengkap dan memadai di suatu sekolah maupun yang merupakan milik pribadi guru, sering tidak diiringi dengan kemampuan para guru untuk memanfaatkannya sebagai media pendukung pembelajaran secara optimal, sehingga peralatan TIK tersebut masih terkesan hanya dijadikan pajangan sebagai simbol kekinian teknologi.

Di Kabupaten Hulu Sungai Utara (HSU) Provinsi Kalimantan Selatan, perkembangan pengimplementasian TIK dalam pembelajaran secara lebih terarah dimulai pada tahun 2003 sejak dibentuknya Jaringan Informasi Sekolah (JIS) Amuntai, sebagai salah satu pelaksanaan program dari Direktorat Pembinaan SMK Kemendikbud. Dalam perkembangan selanjutnya kegiatan JIS Amuntai secara kelembagaan cenderung stagnan, karena semua kegiatan tergantung pada program dan pendanaan dari pemerintah pusat. Namun secara individu beberapa anggota JIS Amuntai tetap berupaya untuk mengembangkan TIK untuk bidang pendidikan secara mandiri sampai terbentuknya Komunitas e-edukasi Hulu Sungai Utara (EDUHUSURA) pada tahun 2009, dengan kegiatan utama melaksanakan pelatihan TIK untuk guru TK/RA, SD/MI, SMP/MTs, SMA/MA/SMK di Kabupaten HSU, selain juga senantiasa mendorong terjadinya sharing keterampilan TIK sesama guru di sekolah. 
Sementara di sisi lain peran aktif Dinas Pendidikan Kabupaten HSU dalam upaya mendorong dan memfasilitasi pengintegrasian TIK dalam proses pembelajaran di sekolah dapat dikatakan sangat minim, karena lebih pada tataran koordinasi pelaksanaan program seperti pada program ICT Center, Jardiknas, dan Schoolnet.

Seperti halnya pada satuan pendidikan lainnya, upaya implementasi TIK dalam pembelajaran di sekolah menengah kejuruan (SMK) diduga juga menghadapi banyak kendala yang dapat mengganggu upaya implementasi tersebut, baik pada mata pelajaran normatif, adaptif, maupun produktif. Kendala-kendala tersebut baik yang bersifat internal yang berhubungan dengan kemampuan sekolah, guru, siswa, kurikulum, maupun yang bersifat eksternal yang berhubungan dengan pemangku kepentingan (stakeholder).

Lebih khusus untuk pembelajaran produktif SMK, TIK idealnya digunakan sebagai media belajar, memfasilitasi guru mengembangkan alat peraga, meningkatkan keterampilan dalam menggunakan animasi untuk meningkatkan pemahaman siswa dari hal yang abstrak menjadi visual, dalam rangka meningkatkan produktivitas hasil belajar, meningkatkan interaksi belajar, dan memamerkan produk belajar yang pada akhirnya meningkatkan kebanggaan siswa serta meningkatkan akuntabilitas guru dalam meningkatkan kapasitas pribadi siswa sesuai dengan tujuan pembelajaran yang telah sekolah tetapkan.
Berangkat dari hal-hal yang telah dikemukakan sebelumnya, maka sangat penting untuk diteliti dan dikaji lebih mendalam tentang keterampilan TIK guru produktif SMK di Kabupaten HSU dan implementasinya dalam pembelajaran, serta kendala-kendala yang menjadi penghambat implementasi tersebut.

Rumusan permasalahan yang dibahas dalam penelitian ini sebagai berikut.

1. Seberapa jauh keterampilan TIK guru produktif SMK di Kabupaten HSU?

2. Seberapa jauh implementasi TIK dalam pembelajaran produktif SMK di Kabupaten HSU?

3. Kendala-kendala apa saja yang menjadi penghambat implementasi TIK dalam pembelajaran produktif SMK di Kabupaten HSU?

Berdasarkan definisi yang diberikan oleh UNESCO Asia and Pacific Regional Bureau for Education and Commonwealth of Learning, bahwa TIK adalah teknologi yang digunakan untuk berkomunikasi dan untuk membuat, mengelola dan mendistribusikan informasi. Dari definisi yang luas, TIK termasuk komputer, internet, telepon, televisi, radio, dan peralatan audiovisual (UNESCO, 2008: 11).

Bondan S. Prakoso dan Rakhmat Januardy (2005: 6) mengemukakan bahwa program TIK di lingkungan Kemendikbud dirancang, disusun, dan dilaksanakan agar dapat memberikan sebesar-besarnya manfaat bagi semua pihak, khususnya komunitas Kemendikbud, yaitu: pimpinan, guru, siswa, pegawai, dan alumni. 
Banyak perubahan yang terjadi dalam pendidikan, dimana TIK merupakan salah satu kekuatan pendorongnya. Salah satu bentuk perubahan itu adalah meningkatnya akses ke TIK di kalangan siswa dan guru baik di rumah maupun di sekolah, tak terkecuali di Indonesia. Sebagaimana yang dilansir oleh Communication and Information Unit UNESCO Bangkok (2008: 6-10) bahwa penggunaan TIK di lingkungan pendidikan di Indonesia yang telah teridentifikasi, yaitu: (1) penggunaan TIK yang paling dominan adalah untuk email; (2) TIK dimasukkan dalam kurikulum di beberapa sekolah; (3) pusat pelatihan swasta menawarkan kursus singkat terkait TIK (misalnya, MS Office, desain web, animasi); (4) anggaran telah dialokasikan untuk fasilitas TIK dan koneksi internet di sekolah; dan (5) pelatihan komputer dasar disediakan untuk guru. Sama halnya dengan negara-negara lain, Indonesia bertekad untuk memanfaatkan penggunaan TIK untuk meningkatkan daya saing nasional.

Perubahan juga terjadi dalam cara pandang memahami keterampilan TIK. Pada awalnya, keterampilan TIK didefinisikan hanya sebagai keterampilan teknis, misalnya kemampuan untuk menggunakan aplikasi pengolah kata atau aplikasi database, kadangkadang bahkan keterampilan pemrograman. Dewasa ini, definisi keterampilan TIK adalah keterampilan digital sebagai kompetensi dalam konteks yang lebih luas (Ilomäki, 2008: 11-12). Keterampilan TIK adalah kompetensi pada bidang pembelajaran, yang mencerminkan pemerataan yang luas dalam keterampilan penggunaan TIK. Keterampilan TIK diadaptasi, ditransfer, dan digunakan sebagai alat untuk membantu transformasi pembelajaran dalam hubungannya dengan keterampilan penting lainnya seperti membaca, berhitung dan pemecahan masalah (MCEETYA, 2005: 2).

Definisi lainnya bahwa keterampilan TIK adalah kemampuan untuk menggunakan teknologi digital, alat komunikasi atau jaringan untuk memecahkan masalah informasi dengan tepat sesuai fungsinya dalam masyarakat informasi (ETS, 2005: 3). Hal senada dikemukakan oleh CETF (2008: 3) bahwa keterampilan TIK/digital adalah kemampuan untuk menggunakan peralatan komunikasi dan teknologi digital dan/atau jaringan untuk mengakses, mengelola, mengintegrasikan, mengevaluasi, membuat dan mengkomunikasikan informasi sesuai fungsinya dalam masyarakat berpengetahuan. Demikian juga bahwa keterampilan TIK adalah kemampuan individu untuk menggunakan TIK secara tepat untuk mengakses, mengelola dan mengevaluasi informasi, mengembangkan pemahaman baru, dan berkomunikasi dengan orang lain untuk berpartisipasi secara efektif dalam masyarakat (MCEETYA, 2005: 2).

Keterampilan TIK/digital dapat dirinci dalam beberapa komponen. Nutt (2010: 14) mengemukakan bahwa keterampilan digital mencakup tiga kemampuan, yaitu kemampuan untuk: (1) menggunakan teknologi digital, alat komunikasi atau jaringan untuk menemukan, mengevaluasi, menggunakan, dan menciptakan informasi; (2) memahami dan menggunakan informasi dalam berbagai format dari berbagai sumber ketika disajikan melalui komputer; dan 
(3) melakukan tugas mereka secara efektif dalam lingkungan digital, yaitu keterampilan yang mencakup kemampuan untuk membaca dan menginterpretasikan media, mereproduksi data dan gambar melalui manipulasi digital, serta mengevaluasi dan menerapkan pengetahuan baru yang diperoleh dari lingkungan digital. Hal senada dan lebih rinci dikemukakan ETS (2005: 4) bahwa terdapat tujuh komponen keterampilan TIK sebagai berikut: (1) menentukan (define); (2) mengakses (access); (3) mengelola (manage); mengintegrasikan (integrate); (5) mengevaluasi (evaluate); (6) membuat (create); dan (7) mengkomunikasikan (communicate).

Dari beberapa definisi tentang keterampilan TIK dan cakupan kompetensi penguasaan dan pemanfaatan TIK yang telah dikemukakan sebelumnya, maka dapat disimpulkan bahwa keterampilan TIK adalah keterampilan digital sebagai kompetensi dalam konteks yang lebih luas, mencakup kemampuan untuk: menggunakan teknologi digital, alat komunikasi atau jaringan untuk menemukan, mengevaluasi, menggunakan, dan menciptakan informasi; memahami dan menggunakan informasi dalam berbagai format dari berbagai sumber; dan melakukan tugas secara efektif dalam lingkungan digital. Dengan mempertimbangkan kondisi objektif tentang perkembangan TIK di Kabupaten HSU yang menjadi tempat penelitian, maka dengan mengadaptasi ICT Teacher Survey yang digunakan oleh Department of Education and Training Western Australia seperti yang dikemukakan oleh AES (2006: 8) dirumuskan tentang kisi-kisi kompetensi keterampilan TIK yang akan diteliti tingkat penguasaannya, yaitu pada aplikasi: (1) navigasi file komputer; (2) email; (3) internet; (4) pengolah kata/naskah; (5) presentasi; (6) pengolah angka/lembar kerja; dan (7) database.

Selanjutnya dilakukan pemetaan terhadap penguasaan keterampilan TIK tersebut dengan membagi menjadi tiga tingkat penguasaan, yaitu: rendah, menengah, dan tinggi.

Salah satu kewajiban guru sebagaimana tercantum dalam Undang-Undang RI No. 14 Tahun 2005 tentang Guru dan Dosen pada Bab IV Bagian Kedua Pasal 20 bahwa dalam melaksanakan tugas keprofesionalannya guru wajib meningkatkan dan mengembangkan kualifikasi akademik dan kompetensi secara berkelanjutan sejalan dengan perkembangan ilmu pengetahuan, teknologi, dan seni. Hal tersebut dipertegas lagi dalam Peraturan Menteri Pendidikan Nasional RI Nomor 16 Tahun 2007 tentang Standar Kualifikasi Akademik dan Kompetensi Guru bahwa salah satu kompetensi guru dalam bidang Pedagogik adalah memanfaatkan TIK untuk kepentingan pembelajaran, yaitu memanfaatkan TIK dalam pembelajaran yang diampu. Disebutkan juga bahwa salah satu kompetensi guru dalam bidang Profesional adalah memanfaatkan TIK untuk mengembangkan diri, yaitu memanfaatkan TIK dalam berkomunikasi dan pengembangan diri.

Dalam Peraturan Pemerintah RI No. 74 Tahun 2008 tentang Guru pada Bab I Pasal 1 ayat (21) disebutkan bahwa Sekolah Menengah Kejuruan (SMK) adalah salah satu bentuk satuan pendidikan formal yang 
menyelenggarakan pendidikan kejuruan pada jenjang Pendidikan Menengah sebagai lanjutan dari SMP, MTs, atau bentuk lain yang sederajat atau lanjutan dari hasil belajar yang diakui sama atau setara SMP atau MTs. Mata pelajaran yang disajikan di SMK dikelompokkan menjadi mata pelajaran: normatif, adaptif, dan produktif. Berdasarkan pengelompokkan tersebut, maka penyebutan guru SMK disesuaikan dengan kelompok mata pelajaran yang diampu, yaitu: guru mata pelajaran normatif, guru mata pelajaran adaptif, dan guru mata pelajaran produktif.

Dari beberapa definisi tentang guru dan SMK yang telah dikemukakan sebelumnya, maka dapat disimpulkan bahwa guru produktif SMK adalah pendidik profesional yang mempunyai kedudukan sebagai tenaga profesional pengampu mata pelajaran produktif pada satuan pendidikan formal yang menyelenggarakan pendidikan kejuruan yaitu SMK.

Suroso dan Adi Winanto (2009: 6) menyatakan bahwa dalam proses pembelajaran TIK dapat dimanfaatkan sebagai alat bantu pembelajaran dapat berupa: (1) alat bantu mengajar bagi guru; (2) alat bantu interaksi antara guru dengan siswa; dan (3) alat bantu belajar bagi siswa.

Penggunaan TIK dalam sistem sekolah di Asia-Pasifik, sebagaimana yang dikemukakan UNESCO (2003: 9) bahwa seperti di bagian lain di dunia telah tersebar luas dan berkembang. Banyak yang percaya bahwa TIK akan mendorong guru untuk mentransformasi proses belajar dan mengajar, dari yang sangat didominasi untuk guru menjadi berpusat pada siswa. Lebih lanjut UNESCO (2005: 161) menyatakan bahwa dalam penciptaan lingkungan belajar dan mengajar yang baru, TIK menawarkan berbagai keuntungan dan memberikan kesempatan untuk: (a) memfasilitasi belajar anak-anak yang memiliki gaya belajar dan kemampuan yang berbeda, termasuk lambat dalam belajar, kurang beruntung secara sosial, cacat mental dan fisik, yang berbakat, dan mereka yang tinggal di daerah terpencil; (b) membuat belajar lebih efektif, melibatkan indra lebih dalam konteks multimedia dan lebih banyak koneksi dalam konteks hypermedia; dan (c) menyediakan konteks internasional yang lebih luas untuk mendekati masalah sebagai respon yang lebih peka terhadap kebutuhan lokal.

Dalam konteks Indonesia, UNESCO (2004: 80-81) mengemukakan bahwa pada sejumlah sekolah di Indonesia TIK telah digunakan secara terpadu dalam pendidikan. Guru yang mempunyai kompetensi TIK ditunjuk sebagai koordinator TIK, yang bertanggung jawab atas pengelolaan penggunaan TIK di sekolah. Realitas yang ada adalah kebanyakan koordinator TIK tidak memiliki latar belakang pendidikan TIK. Oleh karena itu, melatih mereka dalam TIK yang berhubungan dengan keterampilan yang diperlukan. JIS (Jaringan Informasi Sekolah), sebuah program diprakarsai oleh Direktorat PSMK, bertujuan untuk memberikan pelatihan TIK bagi guru dalam jaringan.

Dari beberapa kajian tentang implementasi TIK dalam pembelajaran yang 
telah dikemukakan sebelumnya, maka dapat disimpulkan bahwa pendidikan harus memandang TIK dari sudut pandang pedagogi. Dalam hal ini TIK tidak hanya tentang berapa macam peralatan teknologi dan keterampilan TIK yang dimiliki, namun lebih kepada bagaimana guru menggunakan produk teknologi dan keterampilan TIK dalam mewujudkan pembelajaran yang menarik dan bermanfaat bagi siswa. Selanjutnya dilakukan pemetaan terhadap implementasi TIK dalam pembelajaran tersebut dengan membagi menjadi tiga tingkat implementasi, yaitu: rendah, menengah, dan tinggi.

Upaya untuk mengimplementasikan TIK dalam pembelajaran, ternyata menghadapi kendala-kendala yang menjadi penghambat upaya implementasi tersebut.

Sebagaimana dikemukakan oleh Pelgrum (2001: 173), bahwa hasil survey yang dilakukan terhadap sekolah di 24 negara menunjukkan hambatan serius yang dirasakan oleh praktisi pendidikan dalam upaya mewujudkan tujuan mereka terkait TIK, antara lain: (1) kurangnya jumlah komputer; (2) guru tidak memiliki pengetahuan/keterampilan; (3) kesulitan untuk mengintegrasikan dalam pembelajaran; (4) supervisi dari staf tidak cukup; dan (5) tidak cukup kesempatan mengikuti pelatihan.

Dalam lingkup pendidikan dan pelatihan kejuruan, menurut Haughey sebagaimana yang dikutip UNESCO (2005: 116) diidentifikasi lima isu kebijakan dan perhatian sehubungan dengan hambatan terhadap implementasi TIK dalam pembelajaran: (1) infrastruktur yang tepat harus tersedia untuk menjamin pemerataan akses dan ketepatan pengiriman konten; (2) administrasi, dimana sistem harus menyediakan sumber daya yang memadai dan dukungan untuk integrasi teknologi; (3) pembelajaran, dimana TIK harus digunakan untuk meningkatkan pembelajaran; (4) pengajaran, dimana guru harus siap untuk menggunakan TIK untuk mengajar dan memfasilitasi belajar siswa; dan (5) pengembangan konten yang dapat menjadi mahal dan memakan waktu, dan konten itu sendiri dapat memiliki umur simpan pendek, sementara mengembangkan dan menjaga kualitas tinggi produk pembelajaran yang up-todate merupakan tantangan utama bagi TVET.

Bondan S. Prakoso dan Rakhmat Januardy (2005: 12-15) mengemukakan bahwa dalam konteks Indonesia terdapat lima jenis kendala yang dihadapi saat ini dalam proses pengembangan TIK, yaitu : (1) dukungan kebijakan dari pemerintah daerah; (2) pendanaan dan kesinambungan program; (3) implementasi program; (4) ketersediaan teknologi infrastruktur dan konektifitas; dan (5) pengembangan lokal konten.

Dari kajian tentang kendala-kendala implementasi TIK dalam pembelajaran yang telah dikemukakan sebelumnya, maka dapat diidentifikasi kendala-kendala yang potensial menjadi penghambat, yaitu: dukungan kebijakan dari pemerintah daerah, pendanaan dan kesinambungan program, implementasi program, ketersediaan teknologi infrastruktur dan konektifitas, dan pengembangan lokal konten.

Balanskat, Blamire, dan Kefala (2006: 5) mengemukakan beberapa temuan tentang 
kompetensi dan penggunaan TIK oleh guru, antara lain: (1) guru pengajar sains, matematika, ilmu komputer, dan yang aktif di pendidikan kejuruan adalah pengguna komputer paling intensif di kelas, dengan penggunaan lebih dari $50 \%$ pada pelajaran mereka; (2) dampak terbesar yang ditemukan terkait dengan guru yang merupakan pengguna berpengalaman dan yang dari awal sudah terlibat jauh dengan integrasi TIK dalam pembelajaran; dan (3) guru belum memanfaatkan potensi kreatif TIK dan melibatkan lebih banyak siswa aktif dalam produksi pengetahuan.

Beberapa hasil penelitian lain terkait TIK dan pendidikan kejuruan antara lain: Paryono dan Quito (2010: 2-22) mengemukakan bahwa di bidang pendidikan dan pelatihan kejuruan (Vocational Education and Training/VET), integrasi TIK tidak hanya pilihan tapi juga sebuah kebutuhan untuk membuat proses pendidikan lebih menarik. Temuan penelitian bahwa TIK tidak hanya sebagai alat untuk membuat bahan pelajaran, tetapi juga sebagai alat untuk menyampaikan, kolaborasi, dan diskusi meskipun masih terbatas; Buntat, Saud, Dahar, Arifin, dan Zaid (2010: 645) mengemukakan bahwa TIK memainkan peranan penting untuk membantu guru dalam pengajaran. Perubahan sangat penting untuk program VET dalam mendukung pengembangan tenaga kerja; Omar dan Paryono (2008: 17) mengemukakan bahwa TIK dalam pendidikan telah diidentifikasi sebagai trend dan isu teratas dalam VET; dan Summak dan Samancioğlu (2011: 1) mengemukakan bahwa terdapat perbedaan signifikan antara tingkat implementasi TIK dan skor penggunaan komputer berdasarkan gender dan usia.

Kerangka pikir dalam penelitian ini sebagaimana tergambar pada Gambar 1 berikut:

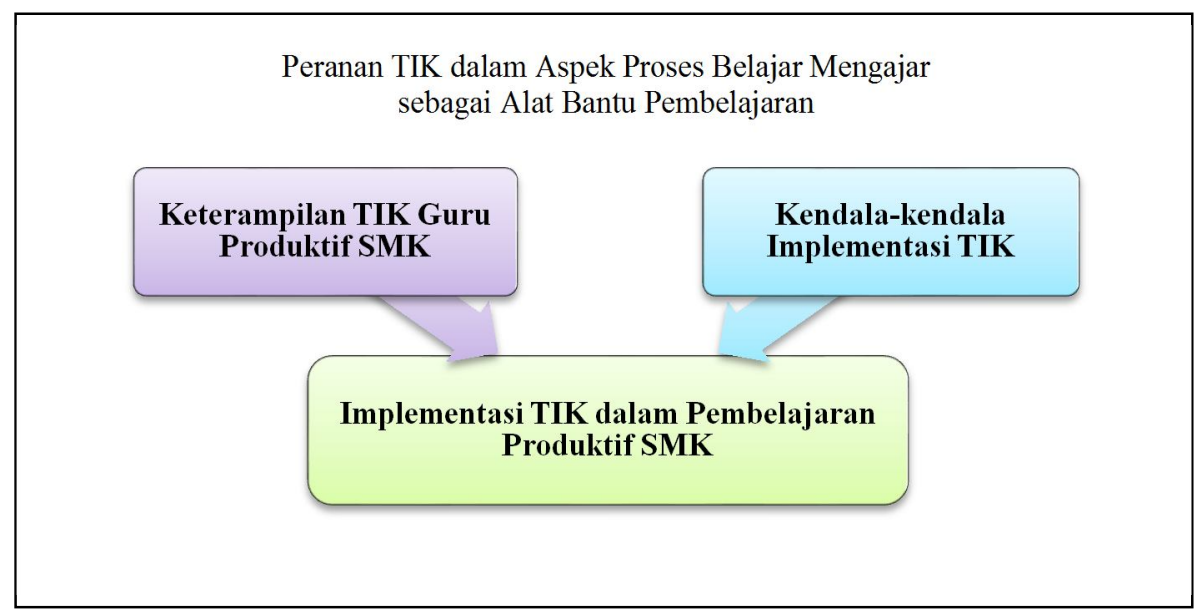

Gambar 1. Kerangka pikir penelitian

Gambar di atas menunjukkan bahwa dalam lingkup peranan TIK dalam aspek proses belajar mengajar, maka pada implementasi TIK dalam pembelajaran produktif SMK, TIK digunakan sebagai alat bantu pembelajaran, yaitu alat bantu untuk: mengajar bagi guru, 
belajar bagi siswa, interaksi antara guru dan siswa. Di sisi lain, diasumsikan penguasaan keterampilan TIK guru produktif SMK merupakan penunjang untuk implementasi TIK dalam pembelajaran produktif SMK, dan sebaliknya terdapat kendala-kendala yang menjadi pengambat implementasi TIK dalam pembelajaran produktif SMK.

Oleh karena itu penelitian ini dirancang untuk mengumpulkan informasi tentang penguasaan keterampilan TIK guru produktif SMK, implementasi TIK dalam pembelajaran produktif SMK, dan untuk mengidentifikasi kendala-kendala yang menghambat implementasi TIK dalam pembelajaran.

\section{METODE}

Penelitian ini adalah penelitian deskriptif menggunakan pendekatan survei. Penelitian dilaksanakan pada empat unit SMK di Kabupaten HSU, yaitu: SMKN 1 Amuntai, SMKN 2 Amuntai, SMKN 3 Amuntai, dan SMK Shalatiyah Bitin. Waktu pelaksanaan penelitian ini dimulai dari bulan Juli 2011 sampai dengan bulan Maret 2012. Populasi penelitian ini adalah seluruh guru produktif SMK di Kabupaten HSU berjumlah 45 orang yang tercatat sebagai guru aktif pada saat penelitian dilaksanakan.

Jenis data penelitian ini adalah data kuantitatif. Data dianalisis secara statistik deskriptif. Instrumen penelitian ini disusun dengan mengadaptasi indikator-indikator implementasi TIK dan indikator-indikator kompetensi keterampilan TIK pada ICT Teacher Survey yang digunakan oleh Department of
Education and Training Western Australia, yang disesuaikan dengan tujuan penelitian.

Instrumen pengumpulan data yang digunakan dalam penelitian ini sebagai berikut.

1. Kuesioner Implementasi TIK dalam Pembelajaran, terdiri dari 26 item pernyataan/pernyataan dengan empat buah alternatif jawaban menggunakan skala Likert.

2. Kuesioner Kendala-kendala Implementasi TIK dalam Pembelajaran, terdiri dari 48 item pernyataan/pernyataan dengan dua buah alternatif jawaban menggunakan skala Guttman.

3. Soal Tes Unjuk Kerja Keterampilan TIK, terdiri dari 10 buah tes unjuk kerja, pada masing-masing tes unjuk kerja terdapat indikator-indikator kompetensi keterampilan TIK.

Pengujian validitas instrumen sebagai berikut.

\section{Pengujian Validitas Isi}

Dalam penelitian ini, untuk menguji validitas isi digunakan pertimbangan pendapat dari ahli (expert judgement), yaitu dikonsultasikan dengan dosen di lingkungan Universitas Negeri Yogyakarta (UNY) yang mempunyai keahlian di bidang TIK, dalam hal ini dengan Dr. Eko Marpanaji, M.T. dan Dr. Ratna Wardani, M.T.

\section{Pengujian Validitas Konstruk}

Untuk pengujian validitas konstruk, dilakukan dengan cara: (1) analisis faktor, yaitu dengan mengkorelasikan antar skor butir instrumen dalam suatu faktor, dan 
mengkorelasikan skor faktor dengan skor total; dan (2) analisis butir, yaitu dengan mengkorelasikan antara skor butir dengan skor total. Dari kedua analisis tersebut akan diperoleh koefisien korelasi $\left(\mathrm{r}_{\mathrm{xy}}\right)$ yang akan diuji untuk memvalidasi konstruk instrumen, yaitu dengan kriteria: jika $r_{x y}>0,3$ maka faktor atau butir tersebut valid.

Untuk kuesioner Implementasi TIK dalam Pembelajaran maupun kuesioner Kendalakendala Implementasi TIK dalam Pembelajaran, setelah dilakukan analisis faktor dan analisis butir, hasil perhitungan menunjukkan koefisien korelasi besarnya lebih dari 0,3. Dengan demikian demikian instrumen memiliki validitas konstruk yang baik.

Pengujian reliabilitas instrumen dilakukan dengan konsistensi internal (internal consistency), yaitu dengan cara mencobakan instrumen sekali saja. Perhitungan koefisien reliabilitas instrumen $\left(\mathrm{r}_{\mathrm{i}}\right)$ dengan data skor interval adalah dengan menggunakan teknik Alfa Cronbach. Untuk kuesioner Implementasi TIK dalam Pembelajaran, setelah dilakukan perhitungan diperoleh koefisien reliabilitas $=$ $0,963>0,6$. Dengan demikian demikian instrumen dinyatakan reliabel. Perhitungan koefisien reliabilitas instrumen $\left(r_{i}\right)$ dengan data skor dikotomi dan jumlah butir pernyataan/pernyataan genap adalah dengan menggunakan teknik Spearman Brown cara pertama yaitu Teknik Belahan Ganjil-Genap. Untuk kuesioner Kendala-kendala Implementasi TIK dalam Pembelajaran, setelah dilakukan perhitungan diperoleh ada hubungan antara pengukuran belahan ganjil dengan pengukuran belahan genap, sehingga instrumen penelitian dinyatakan reliabel.

Untuk dapat menjawab rumusan masalah dan pertanyaan penelitian, maka dilakukan langkah-langkah analisis sebagai berikut.

\section{Analisis Penguasaan Keterampilan TIK Guru Produktif SMK}

1. Menentukan skor: Prosedur Indikator Kompetensi Keterampilan TIK, Bobot Indikator Kompetensi Keterampilan TIK, Indikator Kompetensi Keterampilan TIK, Bobot Kompetensi Keterampilan TIK, dan Kompetensi Keterampilan TIK.

2. Memetakan Kompetensi Keterampilan TIK, dengan mengikuti kurva normal, dengan cara menghitung rerata ideal $\left(\mathrm{M}_{\mathrm{i}}\right)$ dan simpangan baku ideal $\left(\mathrm{SB}_{\mathrm{i}}\right)$ skor Kompetensi Keterampilan TIK dengan menggunakan rumus sebagai berikut.

Rerata ideal $\left(\mathrm{M}_{\mathrm{i}}\right)=$

$$
\frac{1}{2} \cdot\left(X_{\text {maks }}+X_{\text {min }}\right)
$$

Simpangan baku ideal $\left(\mathrm{SB}_{\mathrm{i}}\right)=$

$$
\frac{1}{6} \cdot\left(X_{\text {maks }}-X_{\text {min }}\right)
$$

Keterangan:

$\mathrm{X}_{\text {maks }}=\quad$ skor maksimum kompetensi

$\mathrm{X}_{\min }=\quad$ skor minimum kompetensi

Tabel 1. Kategori Penguasaan Kompetensi

\begin{tabular}{lc}
\hline \hline \multicolumn{1}{c}{ Skor Kompetensi } & $\begin{array}{c}\text { Kategori } \\
\text { Penguasaan } \\
\text { Kompetensi }\end{array}$ \\
\hline \hline $\mathrm{X}<\left(\mathrm{M}_{\mathrm{i}}-1 \mathrm{SB}_{\mathrm{i}}\right)$ & Rendah \\
$\left(\mathrm{M}_{\mathrm{i}}-1 \mathrm{SB}_{\mathrm{i}}\right) \geq \mathrm{X}>\left(\mathrm{M}_{\mathrm{i}}+1\right.$ & Menengah \\
$\left.\mathrm{SB}_{\mathrm{i}}\right)$ & Tinggi \\
$\mathrm{X} \geq\left(\mathrm{M}_{\mathrm{i}}+1 \mathrm{SB}_{\mathrm{i}}\right)$ & \\
\hline
\end{tabular}


3. Menentukan skor: Bobot Keterampilan TIK dan Keterampilan TIK.

4. Memetakan Keterampilan TIK guru produktif SMK, dengan mengadaptasi kriteria pada ICT Teacher Survey yang digunakan oleh Department of Education and Training Western Australia (AES, 2006: 5-6), yaitu:

Tabel 2. Kategori Penguasaan Ketermapilan TIK

\begin{tabular}{cc}
\hline \hline $\begin{array}{c}\text { Skor } \\
\text { Keterampilan TIK }\end{array}$ & $\begin{array}{c}\text { Kategori Penguasaan } \\
\text { Keterampilan TIK }\end{array}$ \\
\hline \hline 0,00 s.d. 39,89 & Rendah \\
39,90 s.d 60,59 & Menengah \\
60,60 s.d. 100,00 & Tinggi \\
\hline
\end{tabular}

\section{Analisis Implementasi TIK dalam Pembelajaran}

1. Menentukan skor perolehan tiap item pernyataan/pertanyaan berdasarkan hasil jawaban pada kuesioner.

2. Menentukan skor perolehan total berdasarkan hasil jawaban pada kuesioner, dengan cara menjumlahkan keseluruhan skor perolehan item pernyataan/pertanyaan.

3. Memetakan Implementasi TIK dalam Pembelajaran, dengan mengikuti kurva normal, dengan acuan:
Tabel 3. Kategori Implementasi TIK dalam Pembelajaran

\begin{tabular}{cc}
\hline \hline $\begin{array}{c}\text { Skor Implementasi } \\
\text { TIK dalam } \\
\text { Pembelajaran }\end{array}$ & $\begin{array}{c}\text { Katergori } \\
\text { Implementasi TIK } \\
\text { dalam Pembelajaran }\end{array}$ \\
\hline $\mathrm{X}<\left(\mathrm{M}_{\mathrm{i}}-1 \mathrm{SB}_{\mathrm{i}}\right)$ & Rendah \\
$\left(\mathrm{M}_{\mathrm{i}}-1 \mathrm{SB}_{\mathrm{i}}\right) \geq \mathrm{X}>$ & Menengah \\
$\left(\mathrm{M}_{\mathrm{i}}+1 \mathrm{SB}_{\mathrm{i}}\right)$ & \\
$\mathrm{X} \geq\left(\mathrm{M}_{\mathrm{i}}+1 \mathrm{SB}_{\mathrm{i}}\right)$ & Tinggi \\
\hline
\end{tabular}

Mengelompokkan Guru SMK Berdasarkan Skor Keterampilan TIK dan Skor Implementasi TIK dalam Pembelajaran

1. Menghitung proporsi untuk sembilan kelompok, untuk memperoleh gambaran penguasaan keterampilan TIK dan implementasi TIK dalam pembelajaran.

2. Selanjutnya dari kesembilan kelompok tersebut di atas dikelompokkan lagi menjadi lima kelompok, yaitu: (1) penguasaan keterampilan TIK tinggi dan implementasi TIK dalam pembelajaran tinggi; (2) penguasaan keterampilan TIK lebih tinggi daripada implementasi TIK dalam pembelajaran; (3) penguasaan keterampilan TIK seimbang dengan implementasi TIK dalam pembelajaran; (4) implementasi TIK dalam pembelajaran lebih tinggi daripada penguasaan keterampilan TIK; dan (5) penguasaan keterampilan TIK rendah dan implementasi TIK dalam pembelajaran rendah. 
Analisis Kendala-kendala Implementasi TIK dalam Pembelajaran

1. Menghitung besaran prosentase jawaban Ya dan Tidak pada tiap item pernyataan/pernyataan.

2. Mengidentifikasi sepuluh besar kendala implementasi TIK dalam pembelajaran produktif SMK.

\section{HASIL PENELITIAN DAN PEMBAHASAN}

Deskripsi dari masing-masing variabel berdasarkan hasil tes unjuk kerja maupun penyebaran kuesioner, hasilnya dapat dijelaskan sebagaimana di bawah ini.

Karakteristik Responden

Tabel 4. Karakteristik Responden

\begin{tabular}{lcc}
\hline \multicolumn{1}{c}{ Karakteristik } & \multicolumn{2}{c}{ Responden } \\
& Jumlah & \% \\
\hline \hline Gender & & \\
\hline Laki-laki & 26 & 57,78 \\
Perempuan & 19 & 42,22 \\
\hline Status Kepegawaian & & \\
\hline Guru Pegawai Negeri Sipil & & \\
(PNS) & 35 & 77,78 \\
Guru Calon Pegawai Negeri & & \\
Sipil (CPNS) & 4 & 8,89 \\
Guru Tetap Yayasan (GTY) & 0 & 0,00 \\
Guru Tidak Tetap (GTT) & 6 & 13,33 \\
\hline Pendidikan Terakhir & & \\
\hline D.3 & 5 & 11,11 \\
D.4/S.0 & 0 & 0,00 \\
S.1 & 39 & 86,67 \\
S.2 & 1 & 2,22 \\
\hline
\end{tabular}

\begin{tabular}{lcc}
\hline \multicolumn{1}{c}{ Karakteristik } & \multicolumn{2}{c}{ Responden } \\
& Jumlah & \% \\
\hline \hline Usia & & \\
\hline Kurang dari 20 tahun & 0 & 0,00 \\
21 hingga 25 tahun & 3 & 6,67 \\
26 hingga 35 tahun & 29 & 64,44 \\
36 hingga 45 tahun & 5 & 11,11 \\
46 hingga 55 tahun & 8 & 17,78 \\
Lebih dari 55 tahun & 0 & 0,00 \\
\hline Tingkat Profesionalitas & & \\
\hline Sudah bersertifikat profesi & 8 & 17,78 \\
Belum bersertifikat profesi & 37 & 82,22 \\
\hline Unit Kerja & & \\
\hline SMK Negeri 1 Amuntai & 16 & 0,36 \\
SMK Negeri 2 Amuntai & 20 & 0,44 \\
SMK Negeri 3 Amuntai & 6 & 0,13 \\
SMK Shalatiyah Bitin & 3 & 0,07 \\
\hline Kompetensi Keahlian & & \\
\hline Pemasaran & 3 & 6,67 \\
Administrasi Perkantoran & 4 & 8,89 \\
Akuntansi & 4 & 8,89 \\
Teknik Komputer Jaringan & 2 & 4,44 \\
Multimedia & 3 & 6,67 \\
Tata Boga & 4 & 8,89 \\
Tata Busana & 9 & 20,00 \\
Teknik Gambar Bangunan & 3 & 6,67 \\
Teknik Kendaraan Ringan & 4 & 8,89 \\
Teknik Sepeda Motor & 3 & 6,67 \\
\hline & & 13,33 \\
\hline
\end{tabular}

Perolehan Skor Kecenderungan Kompetensi Ketermapilan TIK

Keseluruhan perolehan skor kecenderunagn kompetensi keterampilan TIK dirangkum sebagaimana gambae berikut. 


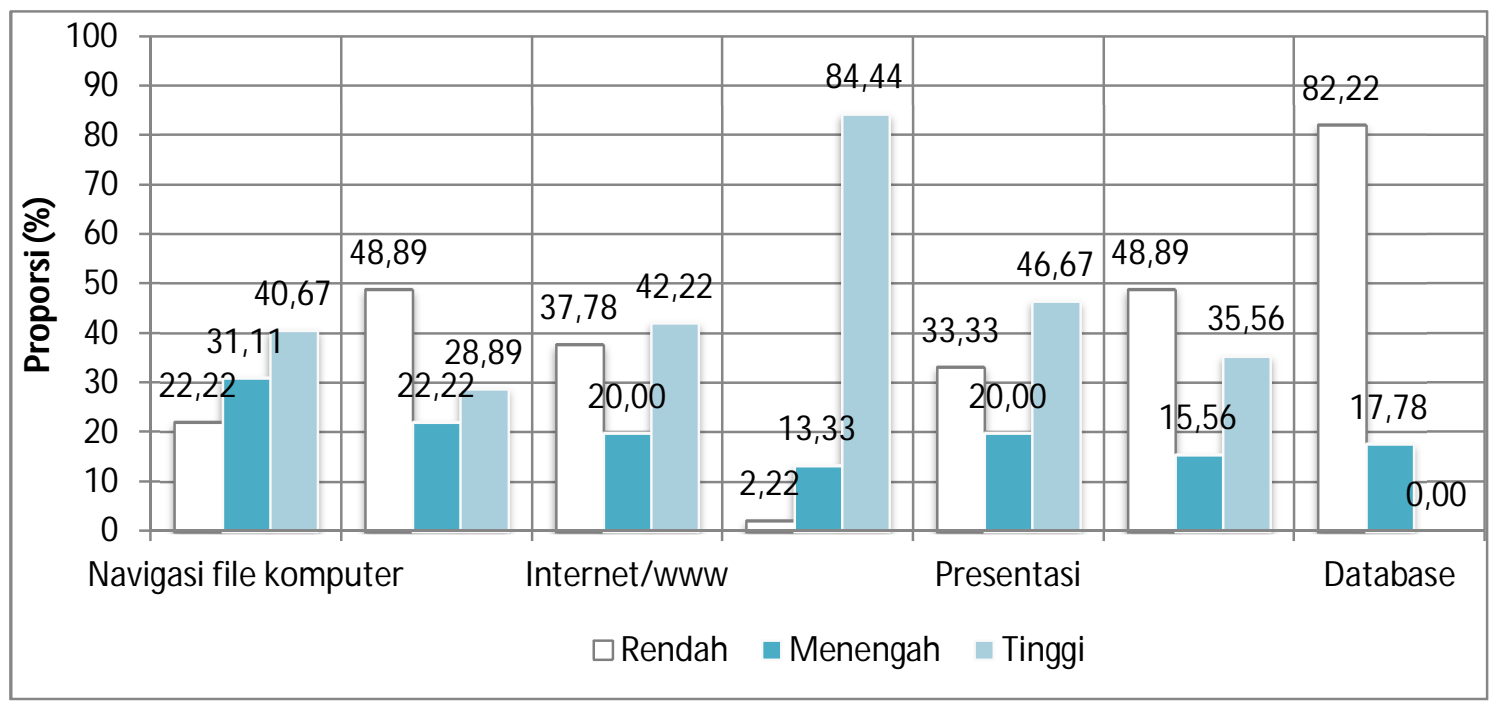

Gambar 2. Rangkuman skor kecenderungan kompetensi keterampilan TIK

\section{Keterampilan TIK Guru Produktif SMK}

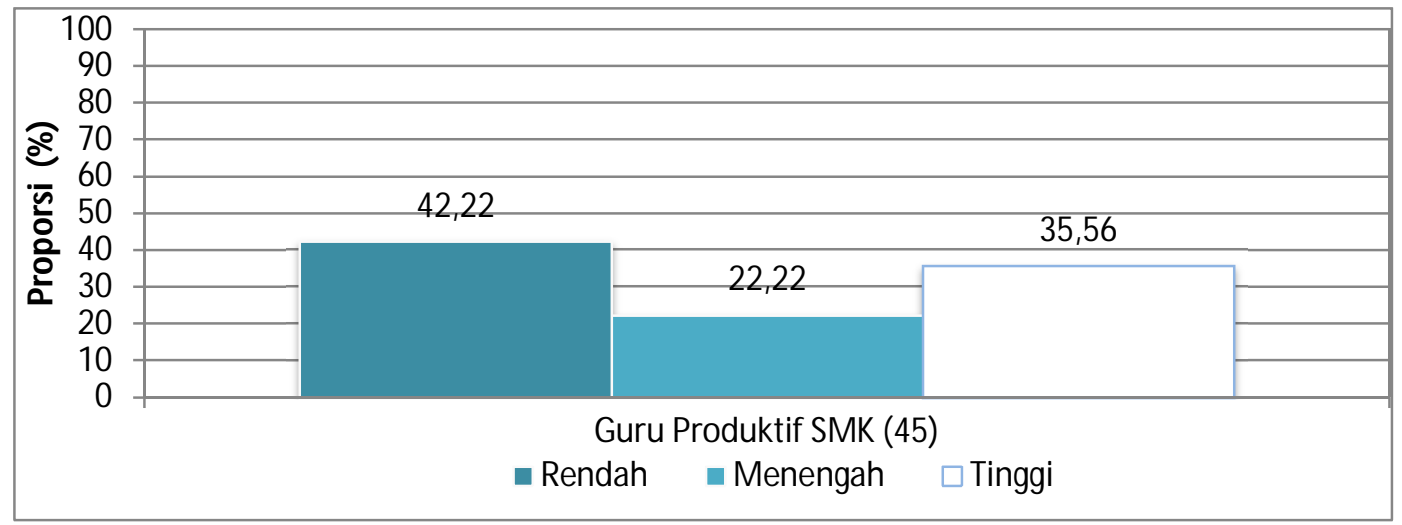

Gambar 3. Keterampilan TIK guru produktif SMK secara keseluruhan

Berdasarkan Gambar 3 di atas, dari keseluruhan 45 orang guru, terdapat $42,22 \%$ termasuk dalam kategori rendah, 22,22\% termasuk dalam kategori menengah, dan 35,56\% termasuk dalam kategori tinggi. Dengan demikian secara keseluruhan keterampilan TIK guru produktif SMK di Kabupaten HSU termasuk dalam kategori rendah, sebagaimana yang ditunjukkan oleh prosentase terbesar pada pemetaan tersebut.

Hal ini menunjukkan bahwa masih diperlukan usaha-usaha untuk meningkatkan keterampilan TIK tersebut, agar dapat menunjang implementasi TIK dalam pembelajaran. Upaya agar guru harus dengan cepat mengupdate pengetahuan, keterampilan, dan kompetensinya dalam bidang TIK, mungkin 
tidak dapat begitu saja dengan mudah dilakukan.

Penyebabnya selain faktor perkembangan TIK yang sangat cepat, di sisi lain terdapat kendalakendala umum mulai dari faktor usia, dukungan sarana/peralatan, kesempatan, dukungan kebijakan dari atasan, hingga ketersediaan infrastruktur di sekolah yang tidak merata dan tidak dengan mudah bisa disesuaikan.

\section{Implementasi TIK dalam Pembelajaran Produktif SMK}

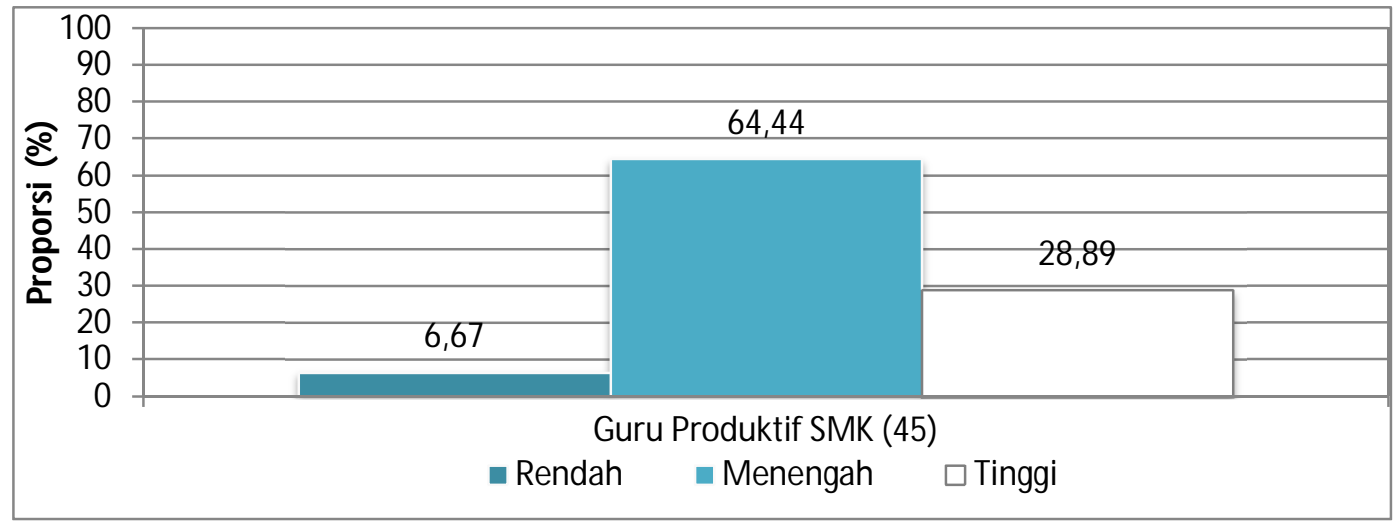

Gambar 4. Implementasi TIK dalam pembelajaran produktif SMK secara keseluruhan

Berdasarkan Gambar 4 di atas, dari keseluruhan 45 orang guru, terdapat $6,67 \%$ termasuk dalam kategori rendah, 64,44\% termasuk dalam kategori menengah, dan 28,89\% termasuk dalam kategori tinggi. Dengan demikian secara keseluruhan implementasi TIK dalam pembelajaran produktif SMK di Kabupaten HSU termasuk dalam kategori menengah, sebagaimana yang ditunjukkan oleh prosentase terbesar pada pemetaan tersebut.

Hal ini menunjukkan bahwa masih diperlukan usaha-usaha untuk meningkatkan implementasi TIK tersebut, agar peranan TIK dalam aspek proses belajar mengajar sebagai alat bantu pembelajaran mencapai hasil yang maksimal. Guru harus dapat menyambut apa yang ditawarkan TIK dalam penciptaan lingkungan belajar dan mengajar yang baru, yaitu keuntungan dan kesempatan untuk: (1) memfasilitasi belajar anak-anak yang memiliki gaya belajar dan kemampuan yang berbeda, termasuk lambat dalam belajar, kurang beruntung secara sosial, cacat mental dan fisik, yang berbakat, dan mereka yang tinggal di daerah terpencil; (2) membuat belajar lebih efektif, melibatkan indra lebih dalam konteks multimedia dan lebih banyak koneksi dalam konteks hypermedia; dan (3) menyediakan konteks internasional yang lebih luas untuk mendekati masalah sebagai respon yang lebih peka terhadap kebutuhan lokal.

Pengelompokkan Guru Produktif SMK Berdasarkan Skor Keterampilan TIK dan Skor Implementasi TIK dalam Pembelajaran 
Tabel 5. Pengelompokkan Guru Produktif SMK Berdasarkan Skor Keterampilan TIK dan Skor Implementasi TIK dalam Pembelajaran secara Keseluruhan

\begin{tabular}{ccccc}
\hline \hline \multirow{2}{*}{$\begin{array}{c}\text { Proporsi Guru SMK } \\
\text { dalam Tiap Kelompok }\end{array}$} & \multicolumn{3}{c}{ Skor Implementasi TIK dalam Pembelajaran } \\
& Tinggi & Menengah & Rendah \\
\hline \hline \multirow{2}{*}{ Skor Penguasaan } & Menengah & $\mathbf{1 7 , 7 8 \%}$ & $\mathbf{1 7 , 7 8 \%}$ & $\mathbf{0 , 0 0 \%}$ \\
Keterampilan TIK & Rendah & $\mathbf{6 , 6 7 \%}$ & $\mathbf{2 8 , 8 9 \%}$ & $\mathbf{6 , 6 7 \%}$ \\
\end{tabular}

Dari 45 orang guru diperoleh gambaran penguasaan keterampilan TIK dan implementasi TIK dalam pembelajaran, yaitu

Sebanyak $17,78 \%$ guru menunjukkan penguasaan keterampilan TIK $\underline{\text { tinggi }}$ dan implementasi TIK dalam pembelajaran tinggi.

Sebanyak $17,78 \%$ guru menunjukkan penguasaan keterampilan TIK lebih tinggi daripada implementasi TIK dalam pembelajaran.

Sebanyak $17,78 \%$ guru menunjukkan penguasaan keterampilan TIK seimbang dengan implementasi TIK dalam pembelajaran.

Sebanyak 40,00\% guru menunjukkan implementasi TIK dalam pembelajaran lebih tinggi daripada penguasaan keterampilan TIK.
Sebanyak 6,67\% guru menunjukkan penguasaan keterampilan TIK $\underline{\text { rendah }}$ dan implementasi TIK dalam pembelajaran rendah.

Hal ini menunjukkan bahwa masih diperlukan usaha-usaha untuk meningkatkan baik keterampilan TIK maupun implementasi TIK. Satu hal yang harus menjadi perhatian adalah perkembangan TIK yang sangat cepat, terkadang membuat penggunanya belum siap untuk memanfaatkannya secara maksimal. Hal inilah yang menjadi tantangan bagi guru untuk mencapai kondisi yang ideal yaitu keterampilan TIK tinggi dan implementasi TIK juga tinggi.

\section{Kendala-kendala Implementasi TIK dalam Pembelajaran Produktif SMK}

Kendala Terkait Dukungan Kebijakan dari Pemerintah Daerah

Tabel 6. Tabel 3. Kendala Terkait Dukungan Kebijakan dari Pemerintah Daerah

\begin{tabular}{lcccc}
\hline \hline \multirow{2}{*}{$\begin{array}{c}\text { Faktor-faktor Kebijakan } \\
\text { Pemerintah Daerah }\end{array}$} & \multicolumn{2}{c}{ Apakah mengetahuinya? } & \multicolumn{2}{c}{$\begin{array}{c}\text { Jika mengetahuinya, apakah } \\
\text { hal tersebut mendukung } \\
\text { implementasi TIK? }\end{array}$} \\
\cline { 2 - 5 } & $\begin{array}{c}\text { Ya } \\
\text { (Jumlah) }\end{array}$ & $\begin{array}{c}\text { Tidak } \\
\text { (Jumlah) }\end{array}$ & $\begin{array}{c}Y a \\
\text { (Jumlah) }\end{array}$ & $\begin{array}{c}\text { Tidak } \\
\text { (Jumlah) }\end{array}$ \\
\hline Komitmen pemerintah daerah untuk & $40,00 \%$ & $60,00 \%$ & $83,33 \%$ & $16,67 \%$ \\
pengembangan TIK & $(18)$ & $(27)$ & $(15)$ & $(3)$ \\
Supervisi dari Dinas Pendidikan & $37,78 \%$ & $62,22 \%$ & $64,71 \%$ & $35,29 \%$ \\
Tim Kerja bidang TIK di Dinas & $(17)$ & $(28)$ & $(11)$ & $(6)$ \\
Pendidikan & $17,78 \%$ & $82,22 \%$ & $100,00 \%$ & $0,00 \%$ \\
Bantuan teknis dari Dinas & $(8)$ & $(37)$ & $(8)$ & $(0)$ \\
Pendidikan & $28,89 \%$ & $71,11 \%$ & $76,92 \%$ & $23,08 \%$ \\
\hline
\end{tabular}


Besaran prosentase kendala menunjukkan masih diperlukannya kebijakan yang lebih jelas dan terarah dari pemerintah daerah, khususnya Dinas Pendidikan selaku pemangku kepentingan utama bidang pendidikan di daerah, terlebih lagi di era otonomi daerah yang menuntut inisiatif dan kreativitas masing-masing daerah terutama untuk pengembangan TIK.

\section{Kendala Terkait Pendanaan dan Kesinambungan Program}

Tabel 7. Kendala Terkait Pendanaan dan Kesinambungan Program

\begin{tabular}{lcccc}
\hline \hline \multirow{2}{*}{$\begin{array}{c}\text { Faktor-faktor Pendanaan dan } \\
\text { Kesinambungan Program }\end{array}$} & \multicolumn{2}{c}{ Apakah mengetahuinya? } & \multicolumn{2}{c}{$\begin{array}{c}\text { Jika mengetahuinya, apakah hal tersebut } \\
\text { mendukung implementasi TIK? }\end{array}$} \\
\cline { 2 - 5 } & $\begin{array}{c}Y a \\
\text { (Jumlah) }\end{array}$ & $\begin{array}{c}\text { Tidak } \\
\text { (Jumlah) }\end{array}$ & $\begin{array}{c}Y a \\
\text { (Jumlah) }\end{array}$ & $\begin{array}{c}\text { Tidak } \\
\text { (Jumlah) }\end{array}$ \\
\hline \hline Dukungan dana dari Dinas & $31,11 \%$ & $68,89 \%$ & $78,57 \%$ & $21,43 \%$ \\
Pendidikan & $(14)$ & $(31)$ & $(11)$ & $(3)$ \\
Dukungan dana dari anggaran & $46,67 \%$ & $53,33 \%$ & $85,71 \%$ & $14,29 \%$ \\
sekolah & $(21)$ & $(24)$ & $(18)$ & $(3)$ \\
Dukungan dana dari pihak swasta/ & $8,89 \%$ & $91,11 \%$ & $75,00 \%$ & $25,00 \%$ \\
masyarakat & $(4)$ & $(41)$ & $(3)$ & $(1)$ \\
\hline
\end{tabular}

Besaran prosentase kendala menunjukkan masih diperlukannya komitmen yang lebih berpihak pada hal-hal penting pada saat perencanaan anggaran pendidikan, mengingat pendidikan adalah tanggung jawab bersama pemerintah, sekolah, dan masyarakat.

Kendala Terkait Implementasi Program

Tabel 8. Kendala Terkait Implementasi Program

\begin{tabular}{lcccccc}
\hline \hline \multirow{2}{*}{$\begin{array}{c}\text { Pengembangan } \\
\text { Profesional di Bidang }\end{array}$ TIK } & \multicolumn{2}{c}{$\begin{array}{c}\text { Apakah pernah } \\
\text { mengikuti? }\end{array}$} & \multicolumn{2}{c}{$\begin{array}{c}\text { Apakah dikelola oleh } \\
\text { sakolah? }\end{array}$} & \multicolumn{2}{c}{$\begin{array}{c}\text { Apakah pengelolaan } \\
\text { tersebut efektif? }\end{array}$} \\
\cline { 2 - 7 } & Tumlah) & $\begin{array}{c}\text { Tidak } \\
\text { (Jumlah) }\end{array}$ & $\begin{array}{c}Y a \\
\text { (Jumlah) }\end{array}$ & $\begin{array}{c}\text { Tidak } \\
\text { (Jumlah) }\end{array}$ & $\begin{array}{c}\text { Ya } \\
\text { (Jumlah) }\end{array}$ & $\begin{array}{c}\text { Tidak } \\
\text { (Jumlah) }\end{array}$ \\
\hline \hline Pelatihan penggunaan & $66,67 \%$ & $33,33 \%$ & $60,00 \%$ & $40,00 \%$ & $83,33 \%$ & $16,67 \%$ \\
komputer dasar & $(30)$ & $(15)$ & $(18)$ & $(12)$ & $(15)$ & $(3)$ \\
Pelatihan Pengolah & $55,56 \%$ & $44,44 \%$ & $72,00 \%$ & $28,00 \%$ & $77,78 \%$ & $22,22 \%$ \\
kata/naskah & $(25)$ & $(20)$ & $(18)$ & $(7)$ & $(14)$ & $(4)$ \\
& $42,22 \%$ & $57,78 \%$ & $57,89 \%$ & $42,11 \%$ & $81,82 \%$ & $18,18 \%$ \\
Pelatihan Internet & $(19)$ & $(26)$ & $(11)$ & $(8)$ & $(9)$ & $(2)$ \\
& $24,44 \%$ & $75,56 \%$ & $45,45 \%$ & $54,55 \%$ & $100,00 \%$ & $0,00 \%$ \\
Pelatihan Manajemen & $(11)$ & $(34)$ & $(5)$ & $(6)$ & $(5)$ & $(0)$ \\
file & $26,67 \%$ & $73,33 \%$ & $50,00 \%$ & $50,00 \%$ & $100,00 \%$ & $0,00 \%$ \\
& $(12)$ & $(33)$ & $(6)$ & $(6)$ & $(6)$ & $(0)$ \\
Pelatihan Email & $40,00 \%$ & $60,00 \%$ & $50,00 \%$ & $50,00 \%$ & $88,89 \%$ & $11,11 \%$ \\
& $(18)$ & $(27)$ & $(9)$ & $(9)$ & $(8)$ & $(1)$ \\
Pelatihan Presentasi & $33,33 \%$ & $66,67 \%$ & $46,67 \%$ & $53,33 \%$ & $100,00 \%$ & $0,00 \%$ \\
Pelatihan Pengolah & $(15)$ & $(30)$ & $(7)$ & $(8)$ & $(7)$ & $(0)$ \\
angka/lembar kerja & $8,89 \%$ & $91,11 \%$ & $50,00 \%$ & $50,00 \%$ & $100,00 \%$ & $0,00 \%$ \\
Pelatihan Database & $(4)$ & $(41)$ & $(2)$ & $(2)$ & $(2)$ & $(0)$ \\
Pelatihan pemanfaatan & $35,56 \%$ & $64,44 \%$ & $37,50 \%$ & $62,50 \%$ & $83,33 \%$ & $16,67 \%$ \\
TIK untuk pembelajaran & $(16)$ & $(29)$ & $(6)$ & $(10)$ & $(5)$ & $(1)$ \\
\hline
\end{tabular}


Besaran prosentase kendala menunjukkan masih diperlukannya inisiatif program dan strategi pengembangan profesional yang lebih

terarah dari pemangku kepentingan di masa yang akan datang.

\section{Kendala Terkait Ketersediaan Teknologi Infrastruktur dan Konektifitas}

Tabel 9. Kendala Terkait Ketersediaan Teknologi Infrastruktur dan Konektifitas

\begin{tabular}{|c|c|c|c|c|c|c|}
\hline \multirow[t]{2}{*}{ Sumber daya TIK } & \multicolumn{2}{|c|}{ Apakah tersedia? } & \multicolumn{2}{|c|}{$\begin{array}{c}\text { Jika tersedia, } \\
\text { pernahkah } \\
\text { menggunakannya? }\end{array}$} & \multicolumn{2}{|c|}{$\begin{array}{c}\text { Apakah mudah untuk } \\
\text { diakses? }\end{array}$} \\
\hline & $\begin{array}{c}Y a \\
\text { (Jumlah) }\end{array}$ & $\begin{array}{c}\text { Tidak } \\
\text { (Jumlah) }\end{array}$ & $\begin{array}{c}Y a \\
\text { (Jumlah) }\end{array}$ & $\begin{array}{c}\text { Tidak } \\
\text { (Jumlah) }\end{array}$ & $\begin{array}{c}Y a \\
\text { (Jumlah) }\end{array}$ & $\begin{array}{c}\text { Tidak } \\
\text { (Jumlah) }\end{array}$ \\
\hline $\begin{array}{l}\text { Komputer/Laptop untuk } \\
\text { guru }\end{array}$ & $\begin{array}{c}80,00 \% \\
(36)\end{array}$ & $\begin{array}{l}20,00 \% \\
(9)\end{array}$ & $\begin{array}{l}94,44 \% \\
(34)\end{array}$ & $\begin{array}{l}5,56 \% \\
(2)\end{array}$ & $\begin{array}{l}79,41 \% \\
(27)\end{array}$ & $\begin{array}{l}20,59 \% \\
(7)\end{array}$ \\
\hline $\begin{array}{l}\text { Komputer/Laptop } \\
\text { pribadi }\end{array}$ & $\begin{array}{c}84,44 \% \\
(38)\end{array}$ & $\begin{array}{l}15,56 \% \\
(7)\end{array}$ & $\begin{array}{c}89,47 \% \\
(34)\end{array}$ & $\begin{array}{c}10,53 \% \\
\quad(4)\end{array}$ & $\begin{array}{c}97,06 \% \\
(33)\end{array}$ & $\begin{array}{l}2,94 \% \\
(1)\end{array}$ \\
\hline Akun email pribadi & $\begin{array}{c}66,67 \% \\
(30)\end{array}$ & $\begin{array}{c}33,33 \% \\
(15)\end{array}$ & $\begin{array}{l}90,00 \% \\
(27)\end{array}$ & $\begin{array}{l}10,00 \% \\
\text { (3) }\end{array}$ & $\begin{array}{l}96,30 \% \\
(26)\end{array}$ & $\begin{array}{l}3,70 \% \\
(1)\end{array}$ \\
\hline Intranet sekolah & $\begin{array}{c}68,89 \% \\
(31)\end{array}$ & $\begin{array}{c}31,11 \% \\
(14)\end{array}$ & $\begin{array}{l}70,97 \% \\
(22)\end{array}$ & $\begin{array}{l}29,03 \% \\
\quad(9)\end{array}$ & $\begin{array}{c}81,82 \% \\
(18)\end{array}$ & $\begin{array}{c}18,18 \% \\
(4)\end{array}$ \\
\hline $\begin{array}{l}\text { Internet sekolah } \\
\text { (LAN/hotspot) }\end{array}$ & $\begin{array}{c}66,67 \% \\
(30)\end{array}$ & $\begin{array}{l}33,33 \% \\
(15)\end{array}$ & $\begin{array}{l}76,67 \% \\
(23)\end{array}$ & $\begin{array}{l}23,33 \% \\
\quad(7)\end{array}$ & $\begin{array}{l}82,61 \% \\
(19)\end{array}$ & $\begin{array}{l}17,39 \% \\
(4)\end{array}$ \\
\hline Internet pribadi & $\begin{array}{l}24,44 \% \\
(11)\end{array}$ & $\begin{array}{l}75,56 \% \\
(34)\end{array}$ & $\begin{array}{l}90,91 \% \\
(10)\end{array}$ & $\begin{array}{l}9,09 \% \\
(1)\end{array}$ & $\begin{array}{l}90,00 \% \\
\quad(9)\end{array}$ & $\begin{array}{l}10,00 \% \\
(1)\end{array}$ \\
\hline Webcam & $\begin{array}{l}26,67 \% \\
(12)\end{array}$ & $\begin{array}{c}73,33 \% \\
(33)\end{array}$ & $\begin{array}{l}75,00 \% \\
(9)\end{array}$ & $\begin{array}{l}25,00 \% \\
(3)\end{array}$ & $\begin{array}{l}100,00 \% \\
(9)\end{array}$ & $\begin{array}{l}0,00 \% \\
\quad(0)\end{array}$ \\
\hline Printer & $\begin{array}{c}95,56 \% \\
(43)\end{array}$ & $\begin{array}{l}4,44 \% \\
(2)\end{array}$ & $\begin{array}{c}83,72 \% \\
(36)\end{array}$ & $\begin{array}{l}16,28 \% \\
(7)\end{array}$ & $\begin{array}{c}100,00 \% \\
(36)\end{array}$ & $\begin{array}{l}0,00 \% \\
(0)\end{array}$ \\
\hline Kamera digital & $\begin{array}{c}75,56 \% \\
(34)\end{array}$ & $\begin{array}{l}24,44 \% \\
(11)\end{array}$ & $\begin{array}{c}64,71 \% \\
(22)\end{array}$ & $\begin{array}{l}35,29 \% \\
(12)\end{array}$ & $\begin{array}{l}100,00 \% \\
(22)\end{array}$ & $\begin{array}{c}0,00 \% \\
(0)\end{array}$ \\
\hline Scanner & $\begin{array}{c}80,00 \% \\
(36)\end{array}$ & $\begin{array}{l}20,00 \% \\
\quad(9)\end{array}$ & $\begin{array}{l}63,89 \% \\
(23)\end{array}$ & $\begin{array}{l}36,11 \% \\
(13)\end{array}$ & $\begin{array}{l}100,00 \% \\
(23)\end{array}$ & $\begin{array}{l}0,00 \% \\
(0)\end{array}$ \\
\hline Handycam/camcoder & $\begin{array}{l}55,56 \% \\
(25)\end{array}$ & $\begin{array}{l}44,44 \% \\
(20)\end{array}$ & $\begin{array}{l}52,00 \% \\
(13)\end{array}$ & $\begin{array}{l}48,00 \% \\
(12)\end{array}$ & $\begin{array}{l}100,00 \% \\
(13)\end{array}$ & $\begin{array}{l}0,00 \% \\
(0)\end{array}$ \\
\hline $\begin{array}{l}\text { Program aplikasi khusus } \\
\text { (CAD, dll.) }\end{array}$ & $\begin{array}{l}37,78 \% \\
(17)\end{array}$ & $\begin{array}{c}62,22 \% \\
(28)\end{array}$ & $\begin{array}{c}64,71 \% \\
(11)\end{array}$ & $\begin{array}{l}35,29 \% \\
\quad(6)\end{array}$ & $\begin{array}{l}81,82 \% \\
\quad(9)\end{array}$ & $\begin{array}{l}18,18 \% \\
(2)\end{array}$ \\
\hline LCD projector & $\begin{array}{c}93,33 \% \\
(42)\end{array}$ & $\begin{array}{c}6,67 \% \\
(3)\end{array}$ & $\begin{array}{l}76,19 \% \\
(32)\end{array}$ & $\begin{array}{l}23,81 \% \\
(10)\end{array}$ & $\begin{array}{c}100,00 \% \\
(32)\end{array}$ & $\begin{array}{l}0,00 \% \\
(0)\end{array}$ \\
\hline $\begin{array}{l}\text { Komputer/Laptop di } \\
\text { kelas }\end{array}$ & $\begin{array}{l}20,00 \% \\
(9)\end{array}$ & $\begin{array}{c}80,00 \% \\
(36)\end{array}$ & $\begin{array}{l}100,00 \% \\
\text { (9) }\end{array}$ & $\begin{array}{c}0,00 \% \\
(0)\end{array}$ & $\begin{array}{l}100,00 \% \\
\text { (9) }\end{array}$ & $\begin{array}{c}0,00 \% \\
(0)\end{array}$ \\
\hline $\begin{array}{l}\text { Komputer/Laptop di } \\
\text { laboratorium }\end{array}$ & $\begin{array}{c}82,22 \% \\
(37)\end{array}$ & $\begin{array}{l}17,78 \% \\
(8)\end{array}$ & $\begin{array}{l}59,46 \% \\
(22)\end{array}$ & $\begin{array}{l}40,54 \% \\
(15)\end{array}$ & $\begin{array}{l}100,00 \% \\
(22)\end{array}$ & $\begin{array}{l}0,00 \% \\
(0)\end{array}$ \\
\hline $\begin{array}{l}\text { Komputer/Laptop di } \\
\text { perpustakaan }\end{array}$ & $\begin{array}{c}77,78 \% \\
(35)\end{array}$ & $\begin{array}{l}22,22 \% \\
(10)\end{array}$ & $\begin{array}{c}42,86 \% \\
(15)\end{array}$ & $\begin{array}{l}57,14 \% \\
(20)\end{array}$ & $\begin{array}{c}93,33 \% \\
(14)\end{array}$ & $\begin{array}{c}6,67 \% \\
(1)\end{array}$ \\
\hline $\begin{array}{l}\text { Komputer/Laptop di } \\
\text { ruang Jurusan }\end{array}$ & $\begin{array}{c}82,22 \% \\
(37)\end{array}$ & $\begin{array}{c}17,78 \% \\
\quad(8)\end{array}$ & $\begin{array}{l}78,38 \% \\
(29)\end{array}$ & $\begin{array}{l}21,62 \% \\
\quad(8)\end{array}$ & $\begin{array}{l}93,10 \% \\
(27)\end{array}$ & $\begin{array}{l}6,90 \% \\
(2)\end{array}$ \\
\hline $\begin{array}{l}\text { Dukungan teknis, } \\
\text { perawatan, perbaikan }\end{array}$ & $\begin{array}{c}77,78 \% \\
(35)\end{array}$ & $\begin{array}{c}22,22 \% \\
(10)\end{array}$ & $\begin{array}{c}62,86 \% \\
(22)\end{array}$ & $\begin{array}{c}37,14 \% \\
(13)\end{array}$ & $\begin{array}{c}81,82 \% \\
(18)\end{array}$ & $\begin{array}{c}18,18 \% \\
(4)\end{array}$ \\
\hline
\end{tabular}


Besaran prosentase kendala menunjukkan diperlukannya perhatian lebih lanjut dalam manajemen sumber daya TIK tersebut, agar dapat dimanfaatkan secara maksimal Untuk itu diperlukan juga penyediaan prasarana penunjang.

Kendala Terkait Pengembangan Lokal Konten

Tabel 10. Kendala Terkait Pengembangan Lokal Konten

\begin{tabular}{lcc}
\hline \multicolumn{1}{c}{ Penggunaan TIK di sekolah } & $Y a$ & Tidak \\
& $($ Jumlah $)$ & $($ Jumlah $)$ \\
\hline \hline Sekolah saya memiliki arah yang jelas dalam bagaimana menggunakan & $68,89 \%$ & $31,11 \%$ \\
TIK untuk meningkatkan pembelajaran siswa & $(31)$ & $(14)$ \\
Sekolah saya mendorong penggunaan TIK oleh semua guru & $86,67 \%$ & $13,33 \%$ \\
Sekolah saya memberikan dukungan strategis yang sama untuk semua & $(39)$ & $(6)$ \\
guru & $80,00 \%$ & $20,00 \%$ \\
Penggunaan TIK didorong dalam praktik belajar dan mengajar di & $(36)$ & $(9)$ \\
sekolah & $86,67 \%$ & $13,33 \%$ \\
Penggunaan TIK disediakan akses yang sesuai & $(39)$ & $(6)$ \\
Guru di sekolah saya didorong untuk berpartisipasi dalam & $68,89 \%$ & $31,11 \%$ \\
pengembangan profesional & $(31)$ & $(14)$ \\
Guru di sekolah saya didukung untuk berpartisipasi dalam & $84,44 \%$ & $15,56 \%$ \\
pengembangan profesional & $(38)$ & $(7)$ \\
TIK digunakan untuk memonitor, mengevaluasi dan melaporkan & $86,67 \%$ & $13,33 \%$ \\
prestasi siswa di sekolah saya & $(39)$ & $(6)$ \\
Sumber daya TIK yang tersedia cukup untuk memenuhi kebutuhan & $71,11 \%$ & $28,89 \%$ \\
TIK untuk guru dan siswa & $(32)$ & $(13)$ \\
Guru di sekolah saya didorong untuk mengembangkan media & $(18)$ & $60,00 \%$ \\
pembelajaran berbasis TIK & $86,67 \%$ & $(27)$ \\
Sekolah saya memberikan penghargaan bagi guru yang & $(39)$ & $(6,33 \%$ \\
mengembangkan media pembelajaran berbasis TIK & $24,44 \%$ & $75,56 \%$ \\
Media pembelajaran berbasis TIK yang dibuat guru mendapat penilaian & $17,78 \%$ & $82,22 \%$ \\
angka kredit & $(8)$ & $(37)$ \\
\hline
\end{tabular}

Besaran prosentase kendala menunjukkan masih diperlukannya penciptaan iklim yang kondusif yang mendukung optimalnya penggunaan TIK di sekolah melalui penyempurnaan manajemen pengembangan sekolah.

Selanjutnya dari keseluruhan kendala tersebut di atas dapat diidentifikasi sepuluh besar kendala implementasi TIK dalam pembelajaran produktif SMK, yaitu:
1. Tidak mengetahui adanya dukungan dana dari pihak swasta/ masyarakat $(91,11 \%)$.

2. Tidak pernah mengikuti pelatihan Database (misal MS-Access) $(91,11 \%)$.

3. Tidak mengetahui adanya Tim Kerja bidang TIK di Dinas Pendidikan (82,22\%).

4. Tidak adanya penilaian angka kredit untuk media pembelajaran berbasis TIK $(82,22 \%)$. 
5. Tidak tersedianya komputer/laptop di kelas $(80,00 \%)$.

6. Tidak pernah mengikuti pelatihan Manajemen File (75,56\%).

7. Tidak tersedianya internet pribadi $(75,56 \%)$.

8. Tidak adanya penghargaan untuk pengembangan media pembelajaran berbasis TIK $(75,56 \%)$.

9. Tidak pernah mengikuti pelatihan Email $(73,33 \%)$.

10. Tidak tersedianya webcam $(73,33 \%)$.

Hal tersebut menunjukkan bahwa kendala implementasi TIK dalam pembelajaran produktif SMK berkaitan dengan kebijakan pemerintah daerah, pendanaan program, pengembangan profesional di bidang TIK, ketersediaan sumber daya TIK, dan penggunaan TIK di sekolah.

\section{SIMPULAN DAN SARAN}

Keterampilan TIK guru produktif SMK, implementasi TIK dalam pembelajaran produktif SMK, serta kendala-kendala implementasi TIK dalam pembelajaran produktif SMK di Kabupaten HSU, dapat disimpulkan sebagai berikut.

1. Keterampilan TIK guru produktif SMK di Kabupaten HSU secara keseluruhan termasuk dalam kategori rendah.

2. Implementasi TIK dalam pembelajaran produktif SMK di Kabupaten HSU termasuk dalam kategori menengah.

3. Kendala-kendala implementasi TIK dalam pembelajaran produktif SMK di Kabupaten
HSU berkaitan dengan kebijakan pemerintah daerah dalam bidang TIK, pendanaan program, pengembangan profesional di bidang TIK, ketersediaan sumber daya TIK, dan penggunaan TIK di sekolah.

Berdasarkan hasil penelitian, analisis data, pembahasan, dan simpulan di atas, maka implikasinya adalah keterampilan TIK guru produktif SMK rendah akan berdampak terhadap implementasi TIK dalam pembelajaran produktif SMK, serta berpotensi untuk mempengaruhi hasil pembelajaran.

Teknologi informasi dan komunikasi adalah suatu alat yang membutuhkan kemampuan untuk memiliki dan menggunakannya. Tiap individu memiliki kemampuan yang berbeda untuk memiliki dan menggunakannya sehingga memunculkan kesenjangan digital (digital divide). Kemajuan dan sifat teknologinya serta harga perangkatnya menyebabkan tingkat perbedaan pemanfaatan TIK. Untuk itu diperlukan suatu rencana pengembangan TIK untuk memenuhi kebutuhan dengan cara menyiapkan fasilitas penghubung TIK yang lengkap dengan personelnya untuk dapat mengeliminasi faktor penyebab terjadinya kesenjangan digital tersebut dalam jangka pendek. Institusi pendidikan, termasuk di dalamnya guru dan siswa harus disiapkan sejak dini menjadi akrab dengan TIK.

Terkait kendala-kendala implementasi TIK, perlunya disadari bahwa tidak semua kendala yang dihadapi tersebut dapat diatasi melalui pendekatan teknologi, karena akar permasalahannya tidak selalu terletak pada 
ketidakmampuan dalam mengembangkan teknologi yang sesuai, tetapi kadang lebih disebabkan oleh faktor-faktor non-teknologi, misalnya kebijakan yang tidak kondusif bagi pengguna TIK. Mengingat luasnya hal-hal yang terkait serta luasnya dampak yang ditimbulkan, maka untuk dapat mengembangkan dan memanfaatkan TIK secara sistematik dan berkelanjutan, dibutuhkan suatu usaha untuk mengintegrasikan dan menyamakan langkah berbagai kebijakan kedalam suatu kerangka kebijakan yang terpadu.

\section{DAFTAR PUSTAKA}

AES. 2006. Teacher ICT Skills: Evaluation of the Information and Communication Technology Knowledge and Skill Levels of Western Australian Government School Teachers, http://www.aes.asn.au/conferences/200 6/papers/012\%20Karen\%20Trimmer .pdf. (Diakses 30 Juli 2011).

Balanskat, A., Blamire, R., \& Kefala, S. 2006. The ICT Impact Report, A Review of Studies of ICT Impact on Schools in Europe. European Schoolnet in the framework of the European Commission's ICT cluster.

Bondan S. Prakoso \& Rakhmat Januardy. 2005. Cetak Biru Pengembangan Teknologi Informasi dan Komunikasi (TIK) Depdiknas. Jakarta: Ditjen Mandikdasmen, Depdiknas.

Buntat, Y., Saud M., S., Dahar A., et al. 2010. Computer Technology Application and Vocational Education: A Review of Literature and Research. European Journal of Social Sciences. 14, Artikel 4, http://www.eurojournals.com/ejss_14_4_ 15.pdf. (Diakses 25 Juli 2011).

CETF. 2008. California ICT Digital Literacy Assessments and Curriculum Framework, http://www.ictliteracy.info/rf.pdf/Californ ia\%20ICT\%20Assessments\%20and\%20C
urriculum\%20Framework. pdf. (Diakses 20 Juli 2011).

Depdiknas. 2008. Peraturan Pemerintah RI Nomor 74, Tahun 2005, tentang Guru.

2007. Peraturan Menteri Pendidikan Nasional RI Nomor 16, Tahun 2007, tentang Standar Kualifikasi Akademik dan Kompetensi Guru.

2005. Undang-Undang RI Nomor 14, Tahun 2005, tentang Guru dan Dosen.

ETS. 2005. Beyond Technical Competence: Literacy in Information and Communication Technology Work, http://www.ets.org/Media/Tests/ICT Literacy/pdf/ICT_Beyond_ Technical_Competence.pdf. (Diakses 22 Juli 2011).

Ilomäki, L. 2008. The Effects of ICT on School: Teachers' and Students' Perspectives. Finland: Department of Teacher Education. University of Turku.

MCEETYA. 2005. National Assessment Program Information and Communication Technology Literacy 2005 Years 6 and 10, An Assessment Domain for ICT Literacy, http://www.iste.org/Libraries/PDFs/Austr alia_ICT_Assessment.sflb.ashx/. (Diakses 21 Juli 2011).

Nutt, J. 2010. Professional Educators and The Evolving Role of ICT in Schools, http://www.cfbt.com/ evidenceforeducation/pdf/ICTinSchoolsweb.pdf. (Diakses 31 Juli 2011).

Omar, M. S. H. \& Paryono. 2008. Current trends and issues in VTET: Seameo Voctech's response,

http://ojs.voctech.org/index.php/seavern/a rticle/view/78/108. (Diakses 30 Juli 2011).

Paryono \& Quito, B. G. 2010. Meta-Analysisof ICT Integration in Vocational and Technical Education in Southeast Asia, http://www.academicjournals.org/ajb $\mathrm{m} / \mathrm{PDF} / \mathrm{pdf} 2011 /$ 18Aug/Saud\%20et\%20al.pdf. (Diakses 30 Juli 2011).

Pelgrum, W. J. 2001. Obstacles To The Integration of ICT in Education: Results 
From A Worldwide Educational Assessment, http://www. users.ntua.gr/vvesk/ictedu/article5_

pelgrum.pdf. (Diakses 30 Juli 2011).

Summak, M. S. \& Samancioğlu, M.. 2011. Assessment of Technology Integration in Vocational Education and Training Schools. International Journal of Education and Development using Information and Communication Technology (IJEDICT). 7, Artikel 1259, http://www.ijedict.dec.uwi.edu/includ e/getdoc.php?id=4465\&article $=$ 1259...pdf. (Diakses 25 Juli 2011).

Suroso \& Adi Winato. 2009. Pemanfaatan ICT Dalam Pembelajaran dan Peningkatan Profesionalisme Guru, http://www.pjjpgsd.dikti.go.id/file.php /1/repository/dikti/BA DIPBPJJ_BATCH_1/Manajemen\%20Ber basis\%20Sekolah/UNIT\%209.pdf.

(Diakses 25 Juli 2011)

UNESCO. 2008. Strategy Framework for Promoting ICT Literacy in The AsiaPacific Region. Bangkok: Asia and
Pacific Regional Bureau for Education, UNESCO Bangkok.

2005. ICT in Schools: A Handbook for Teachers or How ICT Can Create New, Open Learning Environments. Division of Higher Education, UNESCO.

2005. ICT Application in Technical and Vocational Education and Training. Specialized Training Course. Moscow: Institute for Information Technologies in Education, UNESCO.

2004. Integrating ICTs Into Education: Lessons Learned. Bangkok: Asia and Pacific Regional Bureau for Education, UNESCO Bangkok.

2003. Developing and Using Indicators of ICT Use in Education. Bangkok: Asia and Pacific Regional Bureau for Education, UNESCO Bangkok.

2002. Information and Communication Technologies in Teacher Education: A Planning Guide. Division of Higher Education, UNESCO. 